\title{
Analysis on the School-enterprise Cooperation Model of "Two-way Intervention and Deep Integration" of Independent College__ Taking Chengxian College of Southeast University as an Example
}

\author{
$\mathrm{Na} \mathrm{Mi}{ }^{1, a,}$, Lin Zhu ${ }^{1, b}$ and Jinjuan Zhu, ${ }^{1, c}$ \\ ${ }^{1}$ Southeast University Chengxian College, Dongda Road No.6, Nanjing, China \\ a yuqingxiaomi@163.com, b277604469@qq.com, ${ }^{c}$ 715041130@qq.com
}

Keywords: Independent College; School-enterprise Cooperation; Intervention; Protection

\begin{abstract}
Under the pressure of market competition, most independent colleges have embarked on a road of application-oriented talents that is in line with local economic and social development and pursues school-running characteristics. The current school-enterprise cooperation model is one of the models that is win-win situation between universities and enterprises (society). Independent colleges should explore a variety of school-enterprise cooperation models according to their own conditions and educational objects, and in order to ensure the orderly implementation of this cooperation model, promote and guarantee from all aspects.
\end{abstract}

\section{Introduction}

The independent college is an inevitable outcome of the accelerated development and deepening reform of China's higher education. It is an important institutional innovation in the process of China's higher education transitioning from elite education to mass education. It is China's expansion of higher education resources, the effective way to provide higher education services to society and an important measure for the reform of China's higher education system. Independent colleges have faced market competition and employment problems for graduates since its inception. Its flexible school-running mechanism not only makes talent training better close to the needs of society and the market, but also makes the independent college directly face the pressure of market competition. Under this pressure, most independent colleges have embarked on a road of application-oriented talents that is in line with local economic and social development and pursues school-running characteristics ${ }^{[1]}$.

\section{Find the Right Location and Explore Multiple Modes of Cooperation}

Independent colleges must find their own position in the formulation of talent training programs because of the differences in their educational objects. Taking Chengxian College of Southeast University as an example, on the basis of carefully analyzing the conditions of running a school and studying the needs of the development of information industry for the knowledge, ability, quality and hierarchy of computer professionals, the training objective of computer science in Chengxian College of Southeast University is targeted at application undergraduate, application services are mainly for Jiangsu Province and its surrounding areas. In accordance with the general idea of the development of the same professional dislocation with the maternal school, the training program focuses on strengthening the training of professional skills while strengthening the basics and professional foundations. However, how to choose the school-enterprise cooperation mode suitable for its own development and ensure its smooth progress has become a focus and difficulty of school-enterprise cooperation research. How to find a cooperation model that suits the development of the school, has the characteristics of running a school and is connected with the local economic development is the most important thing ${ }^{[2]}$. Take Chengxian College of Southeast University as an example. In 2006, according to the spirit of "The Independent College should cultivate the application-oriented talents with innovative spirit and practical ability as the training goal”, the 
college took the lead in the independent colleges in the province by "3+1" school-enterprise cooperation mode, and since then, it has cooperated with industry leaders such as ChinaSoft, Neusoft, Netbo, Wiscom, Zhanteng and other industries to explore various modes, such as "3+1", co-construction courses, co-construction laboratories, joint construction of majors, etc., students with corporate training as the goal of entering the enterprise every year for 1 to 10 months, more than $60 \%$ of graduation design projects combined with engineering practice, nearly $40 \%$ of students in the enterprise to complete graduation design work .

\section{Two-way Intervention and Deep Integration}

In the process of school-enterprise cooperation, the weak shortcomings of students' practical application ability are constantly exposed: knowledge points, ability points are scattered, programming ability is not strong, software development ability for practical applications is poor, innovation practice ability is weak, and it is impossible to directly connect employment needs and so on. This phenomenon caused the college to reflect on the comprehensive training of the school. It found that the experimental courses are poorly related to each other, the core content of the practice content is not enough, the practice link is open, and the internal driving force of the students is not enough. There is a clear disconnect between teaching and corporate training. To change the current situation of disjointedness, we should not rely solely on the training of seniors, but should extend the cooperation between schools and enterprises, and intervene early to promote the advancement of schools and enterprises ${ }^{[3]}$.

\subsection{Interventional Training Program Development}

When formulating talent training programs, front-line teachers and senior technical personnel of the company jointly discuss the curriculum system and training content, and flexibly adjust according to the changes in the employment market or the development of technology. For example, software industry development requires software tester and software project manager, as well as the software architect. The college has added a number of new courses such as software code development technology, software testing, software quality management, software project management, etc. in the professional direction course; in the teaching plan with the enterprise, a number of courses such as the "Android and oPhone", "development technology", "Java advanced development technology" and "database application development technology" have been added; in order to reflect the new development of the discipline, the latest teaching plans have also been added new courses such as multi-core programming and design patterns, as well as with the new technology lectures related to Internet of things, cloud computing.

\subsection{Interventional Course Content Reform}

Employ industry, enterprise experts and university professors to form a teaching steering committee, and ask them to provide guidance on the innovation of the course teaching content according to the needs of enterprises, industry and the development of new technologies. When revising and perfecting the syllabus, the company is required to provide specific opinions or suggestions on the content and teaching objectives of the course. For example, JAVA has been added Java reflection and dynamic proxy, Java design mode content, and DB architecture added Oracle architecture, physical components, permission allocation, data management and other content. Therefore, the degree of cooperation between the culture content of the profession and the social needs is continuously improved.

\subsection{Interventional Teacher Team Building}

Hire influential experts as honorary professors from corporates to come to the school for new technology lectures every year regularly, such as "mobile application development case and prospects", "Android application development case and prospects", "Oracle complex SQL technology", " Wisdom Internet", etc., to expand the professional vision of teachers. Hire enterprise technicians to serve as part-time teachers to make up for the lack of practical experience of young 
teachers. Select teachers to participate in training and project research and development in oder to accumulate engineering experience. We have established a four-level talent training and support system for professional leaders, young backbone teachers, enterprise technicians and general teachers to comprehensively improve the overall quality of the teaching staff.

\subsection{Intervention to enhance students' professional cognition}

Since 2013, the college has established an internship session during the sophomore summer, organizing students to deepen the enterprise with excellent teacher resources and teaching conditions, and in-depth understanding of the software development process and specifications in the form of project teams, experiencing system analysis, design, coding and release. Students who have mastered the basic software development and debugging skills recognize the shortcomings of their knowledge structure and inject strong motivation for subsequent learning. Students generally reflect that such internships are "very useful, allowing us to find goals early and understand how to learn early", which has also brought great touches to in-hospital teaching. Students have already learned a lot of knowledge related to the senior curriculum in the enterprise, which inevitably puts forward higher requirements for classroom teaching, and urges teachers to deepen the reform of teaching content and teaching methods.

\section{Guarantee School-Enterprise Stable Cooperation}

The whole teaching process of the school is composed of various teaching links that are connected and connected to each other and realized through various teaching links. For this new training mode of school-enterprise cooperation, it is more necessary to cooperate with each other, even in the process of exploration and completion. According to the idea of "talent co-cultivation, process co-management, and sharing of results", a good school-enterprise cooperation mechanism should be formed, and its good operation should be maintained to ensure its sustainable development ${ }^{[4]}$.

Firstly, according to the actual cooperation situation, an organization management organization that meets the requirements of school-enterprise cooperation should be established. It consists of the college leaders, relevant functional departments and department heads. It is based on the development strategy of the college and coordinating and guidance the normal operation of the colleges and universities.

Secondly, it is required that teaching management personnel not only can engage in basic teaching management, but also need to have a good level of communication, and can effectively understand and develop effective management methods for new problems, new objects and new links under the new model. From the teaching (training) syllabus, the teaching (training) method, the composition of the guiding team, the implementation of the principle of teaching students in accordance with the aptitude to the more specific time-based credit arrangement, the arrangement of the teaching place, and the determination of the examination method, there will be new situations and new problems, all need careful communication and arrangement of teaching management personnel, and are responsible for every teacher and student who participates in cooperation.

Finally, to build a stable environment for school-enterprise cooperation, it also requires the support of relevant departments and the internal cooperation of the school. Schools should use the capabilities of all parties, get the policy inclination of relevant functional departments and the strong support of industry associations, and establish and consolidate long-term strategic partnerships with enterprises. The school teaching department should regularly send teachers to the enterprise to study internships and form a system to provide training services for the teachers. The personnel department of the school should evaluate the school-enterprise cooperation as the core element of the profession, and include the participation in enterprise practice and technical services in the scope of teacher work assessment and job title appointment, and provide policy services for improving the treatment of these teachers. The school finance department shall set up special support funds for school-enterprise cooperation from the education expenditure, and manage according to the fund management method to provide funds and management services for 
cooperation $^{[5]}$.

\section{Conclusion}

The connotation and essence of school-enterprise cooperation is to make teaching and production, students and enterprises "close-range" contact, to achieve resource sharing, complementary advantages, improve students' ability to adapt to positions, and to meet the needs of enterprises for high-quality applied talents ${ }^{[6]}$.

\section{Acknowledgements}

The Stage Research Results of 2018 Jiangsu Provincial Department of Education University Philosophy and Social Science Research Fund Project 《Construction of Evaluation Index of School-enterprise Cooperation in Applied Talents Training》, Project Approval NO.2018SJA2077

\section{References}

[1] Xiaoqin Tong, Tao Xu. Discussion on the Training Mode of Applied Innovative Talents in Independent Colleges[J]. Economic research guide, 2018(14):119-120.

[2] Qinfen Lv, Liming Liu, Liangsong Xiao. School-enterprise deep integration-innovation modern application skills training mode [J]. Journal of Qujing Normal University, 2018,37(04):44-48.

[3] Xiaowei Wang, Yuqing Zhai,et al. Exploration and Practice of the Cultivation System of Computer Talents' Practice Ability in Independent Colleges[J]. Experimental technology and management, 2018,35(05):6-9.

[4] Guoli Tang, Yuangan Wang. Talent Cultivation Model of "School-enterprise Integration, Production and Education Integration" and Its Implementation Strategy[J]. Operation and management, 2018(09):155-157.

[5] Xin Lu, Yi Qin, Na Zhao. Thoughts on Constructing the Management and Guarantee Mechanism of School-enterprise Cooperation[J]. Liaoning Higher Vocational Journa. 2013, 15(03): 6-9.

[6] Ying Gui, Xueqin Zhu, Niande Jiang. Exploration on the practice teaching reform of computer professional under school-enterprise cooperation model[P]. Computer Research and Development (ICCRD), 2011 3rd International Conference on,2011. 